
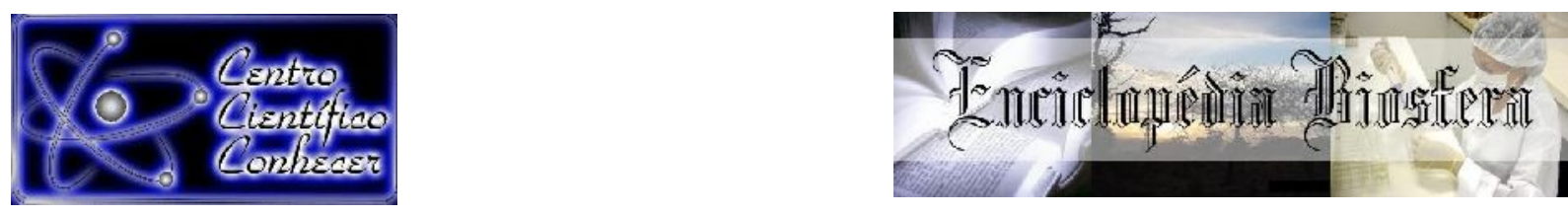

\title{
ONE HEALTH PELA PERSPECTIVA DA SAÚDE AMBIENTAL: INCÊNDIOS FLORESTAIS
}

\author{
Rafael Barros Mothé1; Janas D'arc Barros Siqueira2; Aguinaldo Francisco Mendes \\ Junior'; Gabriele Barros Mothé ${ }^{4}$
}

'Engenheiro Ambiental e Sanitário pela Universidade Estácio de Sá, Macaé, RJ, Brasil.

E-mail do autor correspondente: rafael.eng.ambiental20@gmail.com

${ }^{2}$ Engenheira de Produção pela Universidade Salgado de Oliveira, São Gonçalo, RJ, Brasil.

${ }^{3}$ Médico veterinário e professor da Universidade Santa Úrsula, Rio de Janeiro, RJ, Brasil.

${ }^{4}$ Médica veterinária e professora da Universidade Santa Úrsula e da Universidade de Vassouras - Campus Maricá, Rio de Janeiro, RJ, Brasil.

\section{Recebido em: 15/11/2020 - Aprovado em: 15/12/2020 - Publicado em: 30/12/2020 DOI: 10.18677/EnciBio_2020D28}

\begin{abstract}
RESUMO
One Health é o termo utilizado para conectar a saúde humana e animal com o meio ambiente. Essa união indissolúvel, ambiente-homem-animal, fundamenta a realização de estudos para a difusão dessas informações à população, para que políticas protecionistas possam ser aplicadas e consigam controlar os problemas que comumente afetam a saúde global. Dentre os problemas ambientais que mais preocupam estão os incêndios florestais, que causam perdas irreparáveis para a biodiversidade. No entanto, 0 incêndio acontece, geralmente, devido à ação inconsequente e até mesmo proposital do homem. Por isso, o objetivo desse trabalho é explicitar as causas e salientar as consequências desse ato, para conscientizar a população de que a natureza não é a prova de fogo e os prejuízos podem ser experimentados por todos os seres vivos, sejam vegetais ou animais, inclusive o próprio homem. Nas últimas décadas, o Brasil tem passado por situações alarmantes de incêndios florestais, além de destruição da natureza por outras razões, como: caça e desmatamento. Historicamente, os incêndios florestais também estão relacionados com áreas de desmatamento, somando-se os prejuízos ao meio ambiente. Apesar da legislação proibir essas práticas, falta fiscalização e políticas públicas eficazes no combate aos incêndios florestais. Para que estas políticas protecionistas consigam controlar e prevenir os incêndios florestais, é necessário o conhecimento a respeito dos fatores que os propiciam. Essa é uma questão urgente, pois a natureza precisa ser preservada, os recursos naturais são finitos e a destruição em grande escala compromete a saúde e ameaça a sobrevivência de todos.
\end{abstract}

PALAVRAS-CHAVE: biodiversidade; floresta; fogo; incêndio; queimada. 


\title{
ONE HEALTH FROM THE ENVIRONMENTAL HEALTH PERSPECTIVE: FORESTRY FIRES
}

\begin{abstract}
One Health is the term used to connect human and animal health with the environment. This indissoluble union, environment-man-animal, underlies the realization of studies aimed to the dissemination of this information to the population, so that protectionist policies can be applied and manage to control the problems that commonly affect the global health. Among the environmental problems that most concern are forest fires, which cause irreparable losses to biodiversity. However, the fire usually happens due to the inconsequential and even purposeful action of man. Therefore, the objective of this work is to explain the causes and highlight the consequences of this act, to make the population aware that nature is not fireproof and damage can be experienced by all living beings, whether they are vegetables or animals, including man himself. In the last decades, Brazil has been through alarming situations of forest fires, in addition to the destruction of nature for other reasons, as for hunting and deforestation. Historically, forest fires are also related to deforestation areas, adding to the damage to the environment. Despite the legislation prohibiting these practices, there is a lack of oversight and effective public policies in the fight against forest fires. For these protectionist policies to be able to control and prevent forest fires, it is necessary to know about the factors that propitiate them. This is an urgent matter, as nature needs to be preserved, natural resources are finite and large-scale destruction compromises health and threatens the survival of all.
\end{abstract}

KEYWORDS: biodiversity; burned; conflagration; fire; forest.

\section{INTRODUÇÃO}

O planeta vem sofrendo modificações climáticas devido ao uso indiscriminado dos recursos naturais como manipulação indevida da terra, desmatamento, práticas agrícolas intensivas, incêndios, entre outras práticas humanas inapropriadas (ARAUJO et al., 2019). Tais mudanças nas condições ambientais e habitats resultam no adoecimento do mundo, como um todo, pois propicia agravos à saúde de todos os seres vivos e ecossistemas (ANGELOTTI et al., 2017; HERTE et al., 2017; ARAUJO et al., 2019).

O termo One Health, traduzido para "Saúde única", consiste em um campo do conhecimento, de caráter multiprofissional e interdisciplinar, que reconhece a interconectividade das saúdes ambiental, humana e animal e que tem se tornado uma meta contemporânea de saúde global (SANTOS et al., 2017; MIRANDA, 2018).

Tal conceito foi introduzido no início do milênio, como uma estratégia mundial adotada pela Organização Internacional de Epizotias (OIE), para aplicação de práticas corretas relacionadas à prevenção, vigilância e diagnóstico de doenças animais (incluindo as zoonoses), inocuidade dos alimentos, entre outras questões e problemas sanitários que transcendem à esfera animal e humana, assim como seus determinantes e possíveis soluções (CATENACCI, 2017).

Nesse sentido, a preocupação com o todo é primordial para garantir níveis 
excelentes de saúde, já que essa conectividade entre ambiente, seres humanos e outros animais pode propiciar o surgimento, a reemergência e a disseminação de diversas doenças (ZANELLA, 2016). Por isso, a abordagem One Health é relevante e necessária para entender melhor a interdependência das saúdes ambiental, humana e animal. A priorização desse tipo de estudo, significa realizar vigilância e criar estratégias de prevenção de problemas e a consequente redução da morte de pessoas, animais e do planeta.

Dentre os problemas ambientais que afetam a saúde global pode-se destacar o incêndio florestal, que no Brasil, particularmente, representa um problema grave e crônico. Incêndio florestal é o fogo que invade de forma descontrolada e destrói qualquer tipo de vegetação, seja nativa, ou mesmo a vegetação em áreas rurais, dedicadas a atividades agrícolas e/ou pecuárias. $O$ fogo pode ser iniciado de maneira natural, mas geralmente é fruto da ação humana, de maneira proposital e criminosa (TORRES et al., 2016; FONSECA-MORELLO et al., 2017; CANZIAN et al., 2018; BARREIRA, 2018).

Já a queimada controlada é a utilização de fogo de maneira monitorada, com objetivos definidos, em área e tempo delimitados e com recursos suficientes para extinguir a chama após a conclusão. É utilizada em demasia como forma de manejo em atividades agropastoris ou florestais para preparar o solo para um novo plantio, limpeza e renovação da pastagem para que venha uma nova brotação para o gado (WHITE et al. 2013).

Tanto as queimadas controladas quanto os incêndios florestais são uma das maiores ameaças à preservação da biodiversidade do planeta e importantes fatores de perturbação que influenciam a manutenção dos processos ecológicos dos ecossistemas florestais locais, em especial no Brasil por ser um dos países com a maior biodiversidade do mundo (WHITE et al. 2013). A destruição dos recursos naturais, por desmatamento e incêndios, além da poluição e outros agravos à natureza, ameaça a humanidade, ou seja, ameaça o direito mais importante do homem, o direito à existência (CATENACCI, 2017).

Além dos impactos diretos sobre a fauna e flora natural, Soares e Batista (2007) descrevem que os incêndios podem destruir lavouras, pastos, atingir casas, galpões, armazéns, celeiros e, indiretamente, causar degradação ambiental, deixando o solo mais susceptível a processos erosivos, diminuição da retenção de umidade do solo, assoreamento dos rios, liberação na atmosfera de grande quantidade de gases responsáveis pelo efeito estufa e eventual fragmentação da paisagem (ADÁMEK et al. 2015).

Tais incêndios são particularmente graves para áreas pequenas, em ecossistemas muito sensíveis ao fogo, onde residem espécies raras e/ou ameaçadas de extinção. Nesses locais, grandes incêndios comprometem não apenas a manutenção, mas a sobrevivência de algumas espécies de plantas e animais (FERREIRA et al., 2015). Para Chang et al. (2015), as características dos incêndios florestais geralmente incluem frequência, tamanho e padrão do fogo. Frequência é o número de eventos dentro de uma área especificada durante um determinado período de tempo; tamanho refere-se à extensão da área queimada; e padrão de fogo é a distribuição espacial das ocorrências. Para os autores, estes fatores são afetados pelas 
complexas interações entre a vegetação, clima, topografia e atividades antrópicas ao longo do tempo. De qualquer modo, os incêndios florestais causam perdas irreparáveis à biodiversidade e afetam sobremaneira as saúdes ambiental, humana e animal, afinal todos ocupam os mesmos espaços de convivência, todos habitam o mesmo planeta, numa união indissolúvel que representa a saúde única.

\section{CAUSAS DE INCÊNDIOS FLORESTAIS}

As causas dos incêndios florestais são diversas. No entanto, ocorrem principalmente devido à ação humana, quando o homem age, proposital ou acidentalmente, de maneira irregular e contrária às normas ambientais (COWAN et al., 2016). Uma das principais causas de incêndio é a queimada para limpeza do terreno e formação ou rebrota de pastagens. O homem adota o uso do fogo, principalmente para renovação de pastagens, uma prática primitiva, mas que é utilizada até hoje no intuito de fomentar a pecuária, mesmo sendo ilegal e predatória para o meio ambiente (ALBUQUERQUE et al., 2017; SILVA et al., 2018; LOURENÇO, 2019; CANZIAN et al., 2020).

Além da utilização para a expansão da pecuária, a queimada para limpeza de terreno também é feita na agricultura, para plantações e limpeza de restos de cultura (ALBUQUERQUE et al., 2017). No entanto, já foi comprovado que, com o tempo, essa forma de preparo enfraquece o solo, prejudicando a lavoura e não o contrário; porque, além de enfraquecer a terra, diminui a capacidade do solo de reter umidade, dificulta a recarga dos lençóis freáticos, diminui a vida no solo (pois mata pequenos animais e microrganismos que melhorariam a condição desse solo e o tornariam mais saudável para o crescimento da vegetação), aumentam a chance de erosão e, consequentemente, desmoronamentos de terra; aumentam também o assoreamento de córregos e rios, resultando em inundações; e pode acarretar futuramente em problemas sociais como a diminuição da renda, a fome e a migração de pessoas para outro lugar, cujo terreno ainda seja possível cultivar, ou seja, esse tipo de queimada pode resultar em muitos malefícios a médio e longo prazo (ALBUQUERQUE et al., 2017).

Além de todos esses prejuízos das queimadas para limpeza de terrenos, tanto na agricultura, quanto na pecuária, o homem ainda a faz, muitas vezes, de forma incorreta, sem considerar as condições climáticas e o período de realização. Também não verifica nem providencia aceiros, e, muitas vezes, ainda desconhece os equipamentos que poderiam ser utilizados para o controle do fogo (IBAMA, 2020).

Essa prática também é feita de maneira criminosa e proposital para que o fogo se espalhe, se torne um incêndio e devaste o meio ambiente com o intuito principal de aumentar a área de plantio (ALBUQUERQUE et al., 2017) e por vandalismo também, ou seja, incêndios provocados por má fé (MACEDO; BIAZUSSI, 2017).

Brincadeiras de crianças também podem causar incêndios florestais, pois as crianças não têm discernimento para a manipulação consciente do fogo e podem, acidentalmente, provocar uma devastação. Fogueiras e velas colocadas perto de vegetação, por exemplo, em festas e rituais religiosos, respectivamente, também podem causar incêndios florestais de grandes proporções, principalmente se estiver na época mais seca do ano (ADÁMEK et al., 2015).

A soltura de balões também é muito perigosa pelo risco de causar incêndios 
florestais, e apesar de ser considerada um crime, muitas pessoas ainda insistem nessa prática ilegal (CATENACCI, 2017). Queimada de lixo é outra causa de incêndios florestais e por isso também é crime. Além de ser ilegal, gera poluição e desperdício, já que muito do que é considerado lixo poderia ser reciclado e reaproveitado, levando em consideração a sustentabilidade e a preservação dos recursos naturais do planeta (CATENACCI, 2017).

Os incêndios florestais também podem ser acidentais, causados por máquinas, veículos e cabos de eletricidade, por exemplo. $E$ além de todos esses fatores relacionados à interferência humana, uma pequena parcela dos incêndios florestais pode ser iniciada por causas naturais, tais como raios, principalmente, que geram a ignição caso o ambiente esteja demasiadamente seco. Mas, geralmente, a chuva acompanha os raios e acaba apagando o incêndio, limitando o poder de destruição (MACEDO; BIAZUSSI, 2017). Portanto, não há dúvidas de que o homem é o maior causador de incêndios florestais e deve ter consciência das consequências dos seus atos para preservar a sua própria saúde, dos animais e do meio ambiente.

\section{DETECÇÃO DE FOCOS DE INCÊNDIO}

A análise dos impactos ambientais relacionados aos incêndios florestais é primordial para auxiliar na recomposição do meio afetado e a minimização dos impactos gerados. Soluções para este problema abrangem diversas áreas, desde o levantamento de informações para auxiliar na tomada de decisões da coordenação de combate aos incêndios, o mapeamento dos riscos, a gestão dos materiais inflamáveis, o conhecimento meteorológico local (umidade, temperatura, velocidade e direção do vento, precipitação), a gestão dos meios de combate, análises de ocorrências, avaliação dos efeitos dos incêndios etc (AJIN et al., 2016). Entre as ações implementadas com essa finalidade, o geoprocessamento tem sido uma ferramenta utilizada para auxiliar no processo de tomada de decisão, bem como diminuir as consequências danosas de tais eventos. O mapeamento dos riscos, cuja base teórica mostra sua aplicação em várias partes do mundo (AJIN et al., 2016; BACANI, 2016; MATIN et al., 2017; SAID et al., 2017), é útil para o manejo dos incêndios florestais, no sentido de minimizar os riscos e a propagação dessas ocorrências, além de favorecer uma melhor expressão das fragilidades do território, baseado no entendimento do fenômeno e possibilitando ações de combate mais rápidas e eficientes.

Gai et al. (2011) utilizaram os Sistemas de Informações Geográficas (SIG) para indicar as áreas de maior vulnerabilidade a ocorrências de incêndios florestais, utilizando como fatores de influência o uso da terra, a topografia e a climatologia. Adab et al. (2013) usaram diferentes índices de incêndios florestais, combinando a umidade da vegetação, declividade, aspecto, altimetria, distância das estradas, e uso do solo, para indicar áreas de maior risco ao surgimento de focos de calor, validando os resultados obtidos com focos de calor advindos do sensor MODIS.

Matin et al. (2017) destacam três fatores como principais precursores na ignição e propagação de incêndios florestais resumidos em disponibilidade de combustíveis, temperatura e fator de ignição. Neste trabalho, foram avaliados dados históricos de incidência de incêndios, com o objetivo de explorar os padrões espaciais e temporais de incêndios florestais. Entre as principais variáveis a serem mapeadas para apontar os 
riscos relacionados e a vulnerabilidade das áreas susceptíveis, destacam-se como fatores condicionantes às ocorrências de incêndios: declividade e altimetria, responsáveis pela propagação; uso do solo, temperatura, precipitação e orientação do relevo - principais percussores da ignição (KAZMIERCZAK, 2015).

\section{CONSEQUÊNCIAS DOS INCÊNDIOS FLORESTAIS}

Após anos de interações com a espécie humana, os ecossistemas naturais sofreram alterações que culminaram na presente distribuição das formações vegetais. Para Ferreira et al. (2015), o êxodo rural, a introdução de plantações florestais uniformes e inflamáveis e aumento de áreas degradadas e de pastagem aumentaram a homogeneidade da paisagem, levando a uma ampliação da susceptibilidade à ocorrência de incêndios de grande magnitude.

Tais incêndios geram problemas em diversas escalas, pois afetam sobremaneira as saúdes ambiental, humana e animal, como segue:

A saúde ambiental é ameaçada pelos incêndios florestais, pois estes destroem muitos ecossistemas naturais, causando mudanças climáticas, como aquecimento global, efeito estufa, dentre outros. Ademais, além do incêndio florestal ser comum em períodos secos, este também pode diminuir ainda mais a possibilidade e o volume de chuva naquela região, já que partículas geradas pelos incêndios, como a fuligem, não deixam as nuvens ficarem carregadas o suficiente para que a chuva aconteça, então as nuvens são dispersadas para longe, a água pode evaporar e, assim, não chover justamente onde deveria chover (SANTOS et al., 2015; DIÓGENES et al., 2018; CAVALLI et al., 2019; LOURENÇO et al., 2019).

Já a saúde humana é afetada tanto diretamente, devido aos óbvios agravos à saúde, quanto indiretamente, pois muitos medicamentos são produzidos a partir de substâncias extraídas da flora e da fauna que, uma vez destruídas, cessam o progresso terapêutico e de cura de diversas doenças (ANGELOTTI et al., 2017).

A saúde animal é prejudicada pelos incêndios porque as enfermidades não acometem só os seres humanos, mas também os animais. Mas, no caso destes, estão ainda mais vulneráveis, expostos a queimaduras e muito sofrimento. Inclusive, mesmo para aqueles que não sucumbem ao fogo e conseguem sobreviver, sem o seu habitat, os animais não têm qualidade de vida e precisam migrar em busca de alimento e abrigo, podendo ser atropelados, caçados e morrer por outras causas, inclusive de fome, já que, apesar de ter tido a suposta sorte de sobreviver a um incêndio, tudo o que Ihe servia de alimento pode ter se acabado com o fogo. A morte acontece de qualquer maneira (SANTOS et al., 2015). Quando o fogo alastra, ele pode destruir tudo, matando insetos, pequenos e grandes animais, as árvores e o restante da vegetação, comprometendo a cadeia alimentar e causando grave desequilíbrio ecológico a curto, médio e a longo prazo. Por isso, incêndios são uma grave ameaça à extinção definitiva de diversas espécies animais e vegetais (ANGELOTTI et al., 2017).

De maneira resumida e por dimensão geográfica, localmente os incêndios florestais propiciam a degradação vegetal com a diminuição da densidade arbórea, afetando até a reprodução sexual das plantas com a destruição das flores, frutos e sementes (ALBUQUERQUE et al., 2017), além de danos sobre a biodiversidade eliminando indivíduos de diversas espécies, prejuízos financeiros e em meios de 
subsistência e até perda de vidas humanas. Regionalmente, além dos anteriores, a fumaça e cinzas geram vários agravos à saúde, principalmente respiratórios, afetam os meios de transportes, especialmente os meios aéreos, dentre outros problemas. Já a nível global, há o impulsionamento nas emissões de carbono para a atmosfera, podendo ter consequências para o clima planetário como agravamento do efeito estufa, redução da camada de ozônio, aumento da temperatura média e vivificação dos efeitos do El Niño (HERAWATI; SANTOSO, 2011).

\section{PREVENÇÃO DOS INCÊNDIOS FLORESTAIS}

É importante considerar que a interação do homem com a natureza é relevante e impactante para a saúde e requer o desenvolvimento de atitudes conscientes para prevenir a ocorrência de incêndios florestais e outros problemas ambientais causados especialmente pelo homem (FERREIRA et al., 2015). Prevenir significa não permitir que aconteça e existem diversas formas eficazes de prevenção à incêndios florestais (FERREIRA et al., 2015).

Para que a prevenção seja efetiva, o monitoramento do território nacional e levantamento de dados de áreas atingidas se faz necessário. Para tal, o órgão responsável é o Instituto Nacional de Pesquisas Espaciais (INPE) que, por meio de imagens de satélite, fornece às organizações de controle ambiental, municipais e estaduais, elementos importantes. No site do INPE é possível, gratuitamente e em tempo real, obter dados georreferenciados de mapas, alertas e focos de calor que alimentam a plataforma PREVFOGO que, além de disponibilizar dados sobre focos de queimada, capacita e treina os produtores rurais e brigadistas (IBAMA, 2020).

As particularidades biofísicas e climáticas de cada município, os diferentes usos da terra e os fatores socioeconômicos são imprescindíveis para entender a complexidade que afeta o comportamento dos incêndios florestais, possibilitando melhor salvaguarda dos recursos naturais, biodiversidade e vidas humanas. Tais estudos podem estimar, com precisão, o risco de incêndio a curto prazo, auxiliando nas decisões de mitigação de fogo pelos órgãos competentes (BORGES et al., 2011).

As medidas preventivas mais importantes são relacionadas à transmissão de conhecimento por meio de atividades educativas dirigidas às comunidades rurais, pois, muitas vezes, são estes produtores que ao usarem o fogo como ferramenta de manejo agropecuário ocasionam incêndios florestais de grande magnitude. Como descrito por Ferreira et al. (2015), as atividades preventivas para controle do fogo em áreas rurais têm gerado resultados muito positivos quando os produtores são orientados no local diretamente por técnicos habilitados. É sabido que os hábitos, adequados ou não, decorrem de experiências contínuas de ensino-aprendizagem e podem contribuir para diminuir, manter ou elevar o nível de saúde dos indivíduos. Nesse cenário, a educação é importante para conscientizar e mobilizar a população para que as pessoas tenham mais responsabilidade de seus atos, para gerar engajamento nas questões ambientais e a percepção de que o cuidado com o meio ambiente é importante, pois, se ignorado, pode significar uma ameaça global à saúde, uma vez que a ecologia da saúde ambiental, humana e animal é uma só (MIRANDA, 2018).

Sendo assim, conclui-se que medidas simples podem ser adotadas pela população, tais como destacados a seguir (Quadro 1): 
QUADRO 1: Medidas simples que podem ser adotadas pela população para a prevenção de incêndios florestais.

- Não soltar balões e denunciar quem o faz já que é um crime

- Não atear fogo em lixo e vegetações

- Capinar e manter o terreno da sua moradia e dos arredores sempre limpo

- Utilizar roçagem manual ou com máquina em substituição às queimadas

- Construir aceiros*

*Aceiros são faixas de terreno sem vegetação para diminuir a rapidez de propagação do fogo, como estradas.

- Fazer ou manter barreiras anti-fogo, com árvores que retêm muito líquido e que, por isso, são mais difíceis de queimar. Exemplos desses aceiros naturais são:
o hibisco
$\circ$ jaqueira
○ ingá-amarelo
- ora-pro-nobis
- entre outros

- Cuidar devidamente de crianças para que não brinquem com fogo

- Não jogar bitucas de cigarro no chão e não fumar em locais onde existam materiais combustíveis

- Fazer plantio direto sem remover os restos vegetais para manter a terra coberta, protegida e com menor perda de água e nutrientes

- Adotar a pastagem rotacional e racional para aproveitar melhor o pasto

- Reciclar e reaproveitar as matérias orgânicas e inorgânicas para melhorar a qualidade do solo e descartar menos lixo

- Respeitar as leis

(Fonte adaptada de: ADÁMEK et al., 2015; FERREIRA et al., 2015; COWAN et al., 2016; ALBUQUERQUE et al., 2017; CATENACCI, 2017; MACEDO; BIAZUSSI, 2017; SILVA et al., 2018; LOURENÇO, 2019; CANZIAN et al., 2020) 


\section{CONTROLE DOS INCÊNDIOS FLORESTAIS}

A partir do momento que o incêndio já está fora de controle, as equipes do corpo de bombeiros e brigadistas devem ser chamadas para combater o fogo, que podem ser de três tipos: fogo rasteiro, fogo de copa e fogo oculto (FERREIRA et al., 2015).

O primeiro é o fogo rasteiro, que progride muito rapidamente pela superfície do solo queimando palha, capim seco e pequenos arbustos. Para esses casos, as equipes, além das roupas protetoras, utilizam caminhões-pipa, quando é possível chegar com o veículo próximo ao fogo, bombas portáteis para retirar água de córregos ou lagos próximos, grandes abafadores para suprimir as chamas, criação de aceiros, ao mesmo tempo que queimam uma área estratégica para que o incêndio não encontre combustível para se propagar e eventualmente se apague (FERREIRA et al., 2015).

O segundo tipo é chamado de fogo de copa, que consome as folhas das árvores, chegando a 40 metros de altura, e é mais difícil e perigoso de se combater. Nestes casos, além das técnicas anteriores, usam-se também aviões-tanque e helicópteros que sobrevoam a área despejando água e, em casos mais graves, retardantes de chama, compostos com óxido de ferro, que diminuem o ritmo da combustão, dando mais tempo para que as equipes consigam combater as chamas (FERREIRA et al., 2015).

$\mathrm{O}$ terceiro tipo, e mais traiçoeiro, é o fogo oculto, que queima lentamente o interior de troncos e raízes, como carvão em brasa, e uma rajada de vento pode quebrar e expor esses troncos, recomeçando o incêndio que aparentemente havia sido extinto (FERREIRA et al., 2015).

\section{LEGISLAÇ̃̃O SOBRE INCÊNDIOS FLORESTAIS}

O Brasil possui hoje um dos melhores códigos florestais do mundo. Criado em 25 de maio de 2012 pela Lei 12.651, o novo código florestal estabelece normas gerais sobre a proteção de vegetação nativa, integrando a exploração e suprimento de matéria-prima florestal, áreas de preservação permanente, de reserva legal e de uso restrito e o controle e prevenção de incêndios florestais (BRASIL, 2012).

O código florestal inicialmente proíbe o uso do fogo, mas admite exceções: "Art. 38. É proibido o uso de fogo na vegetação, exceto nas seguintes situações:

II - O emprego da queima controlada em Unidades de Conservação, em conformidade com o respectivo plano de manejo e mediante prévia aprovação do órgão gestor da Unidade de Conservação, visando ao manejo conservacionista da vegetação nativa, cujas características ecológicas estejam associadas evolutivamente à ocorrência do fogo;

$\S 2^{\circ}$ Excetuam-se da proibição constante no caput as práticas de prevenção e combate aos incêndios e as de agricultura de subsistência exercidas pelas populações tradicionais e indígenas" (BRASIL, 2012).

Os artigos 38, 39 e 40 do capítulo IX do código florestal estabelecem a obrigação do governo federal de criação de Política Nacional de Manejo de Controle de Queimadas, Prevenção e Controle aos Incêndios Florestais e as proibições do uso de fogo na vegetação e as exceções específicas como atividades agropastoris ou florestais justificadas pelas peculiaridades da região, tudo mediante aprovação do órgão ambiental estadual competente do Sistema Nacional de Meio Ambiente (BRASIL, 2012). 
Como descrito por Collins et al. (2013), políticas de supressão de incêndios geram benefícios imediatos, mas perdem eficiência ao longo do tempo quando comparadas com investimentos de prevenção. Neste sentido, para instituir políticas de controle e prevenção, faz-se necessário o estudo para traçar o perfil do local, suas características e quando e porque ocorrem os incêndios florestais. Os dados estatísticos são imprescindíveis neste processo. Com essas informações, planeja-se o controle e prevenção de maneira mais eficiente; sem eles, os gastos relacionados à proteção do ambiente serão subestimados ou superestimados, colocando em risco a sobrevivência das florestas (SANTOS et al., 2006).

A política de controle e prevenção de incêndios é planejada e implementada por três níveis do Governo Federal, sendo: o Sistema Nacional de Prevenção e controle de Incêndios Florestais (PREVFOGO), um centro especializado do Instituto Brasileiro do Meio Ambiente e Recursos Naturais Renováveis (IBAMA) e o Instituto Chico Mendes de Conservação da Biodiversidade (ICMBio) (IBAMA, 2020).

Os governos estaduais e municipais atuam, principalmente, por meio dos corpos de bombeiros estaduais, secretarias e órgãos municipais de meio ambiente (IBAMA, 2020). A resolução do Conselho Nacional do Meio Ambiente (CONAMA) nº 011/1988 estabeleceu as normas para o uso correto do fogo no manejo ecológico de áreas de vegetação natural e impôs limites de área total a ser queimada anualmente, de modo a conter e prevenir os incêndios e as emissões atmosféricas (BRASIL, 1988).

No âmbito penal administrativo, há ainda a lei no 9.605/1998 e decreto no $6.514 / 2008$ que, entre outras coisas, preveem reclusão, multas e sanções federais para quem, pessoa física ou jurídica, destrua e/ou danifique - o que inclui cortar e queimar florestas ou demais formas de vegetação, incluso o uso do fogo em áreas agropastoris sem devida autorização (BRASIL, 1998; BRASIL, 2008).

\section{INCÊNDIOS FLORESTAIS NO BRASIL: CENÁRIO ATUAL}

Nos últimos anos o Brasil tem batido recordes de desmatamento e focos de incêndios florestais. Apenas em 2020, no Pantanal, que era o bioma mais bem preservado doPaís, a área queimada foi maior do que a dos últimos 18 anos juntos (INPE, 2020).

Somente em setembro de 2020, o INPE reportou 6.048 pontos de queimadas no pantanal, tornando-se o mês com maior número de focos de incêndio desde o início do monitoramento em 1998. Igualmente na Amazônia, de janeiro a outubro de 2020 foram registrados 89.604 focos de incêndio, superando todo o ano de 2019, que já havia sido muito alto com 89.176 focos (INPE, 2020).

Fatores como forte período de estiagem e aumento da temperatura local, agravado pelo efeito estufa, intensificaram a ocorrência dos incêndios, mas estes não foram os responsáveis pela ignição ou pelo corte, propriamente dito. O desmonte das políticas ambientais, como extinção de centenas de multas ambientais aplicadas a grandes produtores, a redução orçamentária dos órgãos responsáveis pelo monitoramento e combate como IBAMA e ICMBio, impedindo que estes façam seu trabalho de maneira eficaz e rápida, a negligência dos representantes federais e o não aceite de ajuda externa para o devido combate foram cruciais para o alcance desses recordes (INPE, 2020). 


\section{CONSIDERAÇÕES FINAIS}

O Brasil é um país muito rico em biodiversidade, mas o desmatamento e os recorrentes incêndios florestais em diferentes biomas trazem um risco real para todas as formas de vida, inclusive a vida humana. Como consta no Art. 225 da Constituição Federal: "todos têm direito ao meio ambiente ecologicamente equilibrado, bem de uso comum do povo e essencial à sadia qualidade de vida, impondo-se ao poder público e à coletividade o dever de defendê-lo e preservá-lo para as presentes e futuras gerações", o descaso dos representantes governamentais, a aparente falta de interesse em agir a tempo e a impunidade dos infratores agridem ainda mais as delicadas relações ecológicas entre fauna e flora e as colocam em ameaça ou risco de extinção desnecessariamente. Depende da população, enquanto sociedade, compreender a importância dessas relações, traçar medidas para que estes crimes ambientais não mais ocorram e conceber que tais atos, no fim, são crimes contra a humanidade.

\section{REFERÊNCIAS}

ADAB, H.; KANNIAH, K. D.; SOLAIMANI, K. Modeling forest fire risk in the northeast of Iran using remote sensing and GIS techniques. Natural hazards, v. 65, n. 3, p. 17231743, 2013. https://doi.org/10.1007/s11069-012-0450-8

ADÁMEK, M.; BOBEK, P.; HADINCOVÁ, V.; WILD, J.; KOPECKÝ, M. Forest fires within a temperate landscape: a decadal and millennial perspective from a sandstone region in Central Europe. Forest Ecology and Management, v. 336, n. 2015, p. 81-90, 2015. https://doi.org/10.1016/j.foreco.2014.10.014

AJIN, R. S.; LOGHIN, A. M.; VINOD, P. G.; JACOB, M. K. Forest Fire Risk Zone Mapping Using RS and GIS Techniques: A Study in Achankovil Forest Division, Kerala India. Journal of Earth, Environment and Health Sciences, v. 2, n. 3, p. 109-115. 2016. https://doi.org/10.4103/2423-7752.199288

ALBUQUERQUE, E. Z.; DIEHL, E.; SILVA, R. R. Structure of ground-dwelling ant communities in burned and unburned areas in Brazilian subtropical grasslands. Entomological Science, v. 20, n. 1, p. 2017. https://doi.org/10.1111/ens.12270

ANGELOTTI, F.; GHINI, R.; BETTIOL, W. Como o aumento da temperatura interfere nas doenças de plantas? BETTIOL, W.; HAMADA, E.; ANGELOTTI, F.; AUAD, A. M. GUINI, R. Aquecimento global e problemas fitossanitários. Brasília, DF: Embrapa, p. 116-143, 2017.2 Disponível em: https://ainfo.cnptia.embrapa.br/digital/bitstream/item/165241/1/2017LV03.pdf Acesso: $10 / 11 / 2020$

ARAUJO, R. A. F.; UCHÔA, N. M.; ALVES, J. M. B. Influência de variáveis meteorológicas na prevalência das doenças transmitidas pelo mosquito Aedes Aegypti. Revista Brasileira de Meteorologia, v. 34, n. 3, p. 439-447, 2019. http://dx.doi.org/10.1590/0102-7786343054 
BACANI, V. M. Geoprocessing Applied to Risk Assessment of Forest Fires in the Municipality of Bodoquena, MS - Brasil. Revista Árvore, v. 40, n. 6, p. 1003-1011, 2016. http://dx.doi.org/10.1590/0100-67622016000600005

BARREIRA, A. El derecho a un medio ambiente sano: tema pendiente. Tiempo de Paz, v. 129, p. 36-42, 2018. Disponível em: http://revistatiempodepaz.org/revista-129/ Acesso em: $05 / 11 / 2020$

BORGES T. S.; FIEDLER N. C.; SANTOS A. R.; LOUREIRO E. B.; MAFIA R. G. Desempenho de alguns índices de risco de incêndios em plantios de eucalipto no norte do Espírito Santo. Floresta e Ambiente, v. 18, n. 2, p. 153-159, 2011. http://dx.doi. org/10.4322/floram.2011.033.

BRASIL. Constituição da República Federativa do Brasil. Brasília: Senado Federal, 1988. Disponível em: http://www.planalto.gov.br/ccivil_03/constituicao/constituicao.htm Acesso em: 10:11/2020

BRASIL. Decreto n. 6.514, de 22 de julho de 2008. Brasília: Presidência da República, 2008. Disponível em: http://www.planalto.gov.br/ccivil_03/_ato20072010/2008/decreto/d6514.htm Acesso em: 10:11/2020

BRASIL. Decreto n.2.661, de 8 de julho de 1998. Brasília, 1998. Disponível em: http://www.planalto.gov.br/ccivil_03/decreto/d2661.htm Acesso em: 10:11/2020

BRASIL. Lei no 12.651, de 25 de maio de 2012. Brasília: Presidência da República, 2012. Disponível em: http://www.planalto.gov.br/ccivil_03/_ato20112014/2012/lei/l12651.htm Acesso em: 10:11/2020

CANZIAN, W. P.; FIEDLER, N. C.; LOUREIRO, E. B.; BERUDE, L. C. Eficiência do uso da água em métodos de combate a incêndios em florestas plantadas. Nativa, Sinop, v. 6, n. 3, p. 309-312, 2018. http://dx.doi.org/10.31413/nativa.v6i3.4778

CANZIAN, W. P.; FIEDLER, N. C.; PEZZOPANE, J. E. M.; OLIVEIRA, C. H. R.; SILVA, E. C. G. Análise de causa e influência de elementos meteorológicos em ocorrências de incêndios em florestas de produção. Ciência Florestal, v. 30, n. 3, p. 835-844, 2020. https://doi.org/10.5902/1980509837802

CATENACCI, L. S. Abordagem "one health" para vigilância de arbovírus na Mata Atlântica do Sul da Bahia, Brasil. Tese de doutorado, 2017. Disponível em: https://patua.iec.gov.br/handle/iec/3073 Acesso em: 12/11/2020

CAVALLI, A.; FIGUEIREDO, T.; FONSECA, F.; HERNÁNDEZ, Z. Incêndios e áreas ardidas nos últimos 25 anos do distrito de Bragança, Portugal: análise e estimative de consequências para o recurso solo. Territorium, v. 26, n. 1, p. 123-132, 2019. http://dx.doi.org/10.14195/1647-7723_26-1_9 
CHANG, Y.; ZHU, Z.; BU, R.; LI, Y.; HU, Y. Environmental controls on the characteristics of mean number of forest fires and mean forest area burned (1987-2007) in China. Forest Ecology and Management, v. 356, p. 13-21, 2015. https://doi.org/10.1016/j.foreco.2015.07.012

COLLINS, R. D.; NEUFVILLE, R.; CLARO, J.; OLIVEIRA, T.; PACHECO, A. P. Forest fire management to avoid unintended consequences: a case study of Portugal using system dynamics. Journal of Environmental Management, v. 130, n. 2013, p. 1-9, 2013. https://doi.org/10.1016/j.jenvman.2013.08.033

COWAN, A. D.; SMITH, J. E.; FITZGERALD, S. A. Recovering lost ground: Effects of soil burn intensity on nutrientes and ectomycorrhiza communities of ponderosa pine seedlings. Forest Ecology and Management, v. 378, p. 160-172, 2016. https://doi.org/10.1016/j.foreco.2016.07.030

DIÓGENES, F. E. G.; GUIMARÃES, P. P.; BOTREL, R. T. Ocorrência de incêndios florestais em Caicó e Natal - RN. Agropecuária Científica no Semiárido, v. 14, n. 1, p. 80-84, 2018. Disponível em: https://www.researchgate.net/profile/Francisco_Edislan/publication/324375026_Ocorren cia_de_incendios_florestais_em_Caico_e_Natal_-

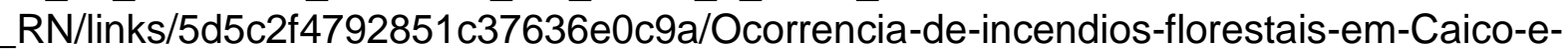
Natal-RN.pdf Acesso em: 08/12/2020

FERREIRA, A. J. D.; ALEGRE, S. P.; COELHO, C. O. A.; SHAKESBYR, A.; PÁSCOA, F. M. Strategies to prevent forest fires and techniques to reverse degradation processes in burned areas. Floram v. 128, p. 224-237, 2015. http:// dx.doi.org/10.1016/j.catena.2014.09.002.

FONSECA-MORELLO, T. R.; RAMOS, R.; STEIL, L.; PARRY, L.; BARLOW, J.; MARKUSSON, N.; FERREIRA, A. Fires in Brazilian amazon: why does policy have a limited impact? Ambiente \& Sociedade, v. 20, n. 4, p. 19-38, 2017. Disponível em: https://www.redalyc.org/pdf/317/31754711003_5.pdf Acesso em: 05/12/2020

GAI, C.; WENG, W.; YUAN, H.; GIS-Based Forest Fire Risk Assessment and Mapping. In: 4th INTERNATIONAL JOINT CONFERENCE ON COMPUTATIONAL SCIENCES AND OPTIMIZATION, Yunnan. Conference paper, China, IEEE, v. 4, p. 1240-1244, 2011. https://doi.org/10.1109/CSO.2011.140

HERAWATI, H.; SANTOSO. H. Tropical forest susceptibility to and risk of fire under changing climate: a review of fire nature, policy and institutions in Indonesia. Forest Policy and Economics, v. 13, p. 227-233, 2011. http://dx.doi. org/10.1016/j.forpol.2011.02.006.

HERTE, M. C.; BELING, E. L.; TOURINHO, M. I. G. Dengue, zica e chikungunya: 
análise da cobertura do risco de doenças associadas às mudanças climáticas sob a ótica do jornalismo ambiental. Anuario Electrónico de Estudios em Comunicación Social, "Disertaciones", $\quad$ v. $\quad 10, \quad n . \quad 2017$. https://doi.org/10.12804/revistas.urosario.edu.co/disertaciones/a.4790

IBAMA - Instituto Brasileiro de Meio Ambiente e dos Recursos naturais renováveis Sistema Nacional de Informações Sobre Fogo - SISFOGO. Disponível em: http://siscom.ibama.gov.br/sisfogo/. Acesso em: 18/10/2020

INPE - Instituto Nacional de Pesquisas espaciais - Monitoramento dos focos ativos por estados. - Disponível em: http://queimadas.dgi.inpe.br/queimadas/portalstatic/estatisticas_estados/. Acesso em: 03/10/2020

KAZMIERCZAK, M. L. Sensoriamento Remoto para Incêndios Florestais. In: SAUSEN, T.M. \& LACRUZ, M. S. P. (eds.). Sensoriamento remoto para desastres. Editora Oficina de Textos, p. 142-168, 2015.

LOURENÇO, L. Grandes incêndios florestais de 17 de junho de 2017 em Portugal e exemplos de determinação das respectivas causas. Territorium: Revista Internacional de Riscos, v. 26, n. 2, p. 1-10, 2019. https://doi.org/10.14195/1647$7723 \_26-24$

LOURENÇO, L.; TEDIM, F.; FERREIRA, C. Os incêndios florestais. Em busca de um novo paradigma. II Diálogo entre Ciência e Utilizadores. Núcleo de Investigação Científica de Incêndios Florestais - Faculdade de Letras da Universidade de Coimbra, NICIF: Coimbra, 2019, 36p. https://doi.org/10.34037/978-972-8330-25-5_2

MACEDO, J. N.; BIAZUSSI, H. M. Queimadas: impactos ambientais e a lei 9.605/98. Revista Científica do CEDS, n. 7, 2017. Disponível em: http://www.undb.edu.br/ceds/revistadoceds/ Acesso em: 07/11/2020

MATIN, M. A.; CHITALE, V. S.; MURTHY, M. S.; UDDIN, K.; BAJRACHARYA, B.; PRADHAN, S. Understanding Forest Fire Patterns and Risk in Nepal Using Remote Sensing, Geographic Information System and Historical Fire Data. International Journal of Wildland Fire, v. 26, n. 4, p. 276-286, 2017. http://dx.doi.org/10.1071/WF16056

MIRANDA, M. A contribuição do médico veterinário na saúde única - one health. I Fórum de Iniciação Científica da Faculdade Patos de Minas, v. 4, s. 1, p. 34, 2018.

SAID, S. N. M. B. M.; ZAHRAN, E. S. M. M.; SHAMS, S. Forest fire risk assessment using hotspot analysis in GIS. The Open Civil Engineering Journal, v. 11, p. 786-801, 2017. http://dx.doi.org/10.2174/1874149501711010786

SANTOS, J. F.; SOARES, R. V.; BATISTA, A. C. Perfil dos incêndios florestais no Brasil em áreas protegidas no período de 1998 a 2002. Floresta, v. 36, n. 1, p. 93-100, 2006. http://dx.doi.org/10.5380/rf.v36i1.5510 
SANTOS, R. C.; BATISTA, A. I.; COELHO, R. D. F.; PILLISSANI, K.; NASCIMENTO JÚNIOR, J. A. Ações para formação continuada em saúde única na Vale do São Francisco. VIII Conferência Internacional de Medicina Veterinária do Coletivo, p. 76-77, 2017. Disponível em: https://www.revistamvezcrmvsp.com.br/index.php/recmvz/article/view/37671 Acesso em: 05/11/2020

SANTOS, W. DE S.; SOUTO, P. C.; SOUTO, J. S.; MENDONÇA, I. F. C. de; SOUTO, L. S.; MARACAJÁ, P. B. Estimativa dos riscos de ocorrência de incêndios florestais no Parque Estadual Pico do Jabre, na Paraíba. Agropecuária Científica do Semiárido, Patos, v. 11, n. 1, p. 80-84, 2015. http://dx.doi.org/10.30969/acsa.v11i1.649

SILVA, E. C. G.; FIEDLER, N. C.; JUVANHOL, R. S.; SILVA, G. M. A.; NEVES, F. P. Análise temporal da ocorrência de incêndios florestais nas Américas e Região do Caribe. Nativa, v. 6, n. 5, p. 491-497, 2018. https://doi.org/10.31413/nativa.v6i5.5845

SOARES, R. V.; BATISTA, A. C. Incêndios Florestais: controle, efeitos e uso do fogo. Curitiba: UFPR, Editora UFV, 1ํㅡㄹ edição, 264 p., 2007.

TORRES, F. T. P.; LIMA, G. S.; COSTA, A. G.; FÉLIX, G. A.; JUNIOR, M. R. S. Perfil dos incêndios florestais em unidades de conservação brasileiras no período de 2008 a 2012. Revista Floresta, v. 46, n. 4, p. 532-542, 2016. http://dx.doi.org/10.5380/rf.v46i4.44199

WHITE, B. L. A.; WHITE, L. A. S.; RIBEIRO, G. T.; FERNANDES, P. A. M. Development of a fire danger index for Eucalypt plantations in the northern coast of Bahia, Brazil. Floresta, v. 43, n. 4, p. 601-610, 2013. http://dx.doi.org/10.5380/rf.v43i4.30973

ZANELLA, J. R. C. Zoonoses emergentes e reemergentes e sua importância para saúde e produção animal. Pesquisa agropecuária brasileira, v. 51, n. 5, p. 510-519, 2016. https://doi.org/10.1590/S0100-204X2016000500011 